Article

\title{
Understanding the Possible Contamination of Ancient Starch Residues by Adjacent Sediments and Modern Plants in Northern China
}

\author{
Zhikun Ma ${ }^{1,2}$, Chi Zhang ${ }^{1}$, Quan $\mathrm{Li}^{2}$, Linda Perry ${ }^{3}$ and Xiaoyan Yang ${ }^{2, *}$ \\ 1 School of Archaeology and Museology, Peking University, Beijing 100871, China; \\ mazhikun123456@163.com (Z.M.); cscazc@pku.edu.cn (C.Z.) \\ 2 Laboratory of Land Surface Pattern and Simulation, Institute of Geographic Sciences and Natural \\ Resources Research, Chinese Academy of Sciences, Beijing 100101, China; quanli_cas@163.com \\ 3 The Foundation for Archaeobotanical Research in Microfossils, P.O. Box 37, Fairfax, VA 22038, USA; \\ linda.at.the.farm@gmail.com \\ * Correspondence: yangxy@igsnrr.ac.cn; Tel.: +86-10-6488-9443
}

Academic Editor: Marc A. Rosen

Received: 16 March 2017; Accepted: 29 April 2017; Published: 5 May 2017

\begin{abstract}
The potential contamination of ancient residues from both modern plant sources and sediments adjacent to archaeological contexts can complicate interpretation in the field of starch grain analysis, thus affecting the sustainable use of the method in archaeobotany. In this study, we examined two potential sources of contamination at a wheat field in Shandong Province and a maize field in Beijing, the Nanzhuangtou site in Hebei Province and the Zhuannian site in Beijing in Northern China. Surface soils from active farmland and its surrounds, as well as deposits from clearly-defined cultural layers, overlying layers, and underlayers at the archaeological sites were subjected to starch grain analysis. No starches were recovered from any of the 16 surface soil samples from fields of wheat and maize, or their environs. This outcome indicates that starches do not preserve well in active surface soils. Further results from the analysis of 33 samples from the two sites demonstrate that starches do not occur in either the overlying layers or underlayers of cultural deposits. Thus, starch grains extracted from the surface residues of artifacts were not deposited from adjacent sediments after the artifacts were abandoned or buried. Further, cultural sediments contained fewer starch grains than the surfaces of artifacts in the same horizon. Thus, if any starch grains on the surfaces of tools are the result of contamination, ancient cultural sediments are the primary source. In conclusion, we offer insights for the prevention of misinterpretation of extraneous residues and sustainable development for the use of starch grain analysis.
\end{abstract}

Keywords: starch grain analysis; potential contamination; cultural deposits; sustainable use

\section{Introduction}

The recovery of botanical remains from archaeological contexts and subsequent analysis of ancient plant use relies upon the analysis of macroremains (e.g., charred seeds and stems) and microremains (e.g., pollen, phytoliths, and starch grains) [1-4]. One of the most prominent archaeobotanical methods of analyzing plant microremains is starch grain analysis, used increasingly since the 1980s, especially in the Americas [4-7], Oceania [8], and East Asia [9-13]. Using the morphological characteristics of modern starch grains, researchers compare, identify, and both quantitatively and qualitatively analyze the ancient starch grains recovered from sediments, stone tools, pottery, and dental calculus. These achievements have improved our understanding of ancient plant use and clarified the functions of plant-related implements [4-7,9-11,14-17]. 
As the methods of organic residue analysis have grown more popular, criticism has also arisen regarding the possibility of post-depositional contamination that could possibly confound analyses and hinder the sustainable use of the method. Potential contamination on artifact surface residues could occur in the processes of deposition, excavation, storage, and pre-treatment of samples in the laboratory. Proper procedural precautions employed by operators, however, minimize the possibility of contamination in the latter three stages. Therefore, the depositional environment of artifacts is the most uncontrolled factor and the most likely cause of starch grain contamination if it is, in fact, occurring. The issue is exacerbated by our current lack of knowledge regarding the mechanisms behind organic preservation, meaning it is difficult to pinpoint where, exactly, contamination could occur $[18,19]$. Concerns include the possibilities that the residue may have been deposited from the surface soil of nearby areas covered by starch-rich vegetation after the artifacts were abandoned or buried, or starch residues may be sourced from ancient sediments surrounding the archaeological context in question.

Previous studies provide some insight into the issue of starch grain deposition from surrounding soil onto artifacts. Initial simulations of the three-dimensional movements of starch grains through sediments found that they do not show significant transfer through a soil profile [20,21], although more recent work [20] suggests limited movement within a sandy soil matrix. Moreover, controlled experiments placing clean and recently-used artifacts in contact with materials, such as meats, leathers, and vegetables, indicated that although some residue transfer occurs, starch grains do not arbitrarily "jump" from the surroundings onto nearby artifacts [22]. While these simulation results are encouraging for organic residue analyses, we currently lack field data on whether starches in surface soils and sediments may cause contamination of artifacts.

This study is a field test to determine whether starch grain residues on artifacts are affected by surface soil or archaeological sediments that are adjacent to studied artifacts. Samples from both modern agricultural surface soils and deposition samples at archaeological sites were collected and subjected to starch grain analysis. Our aims are to provide preliminary data on the potential for artifact contamination from these soils and sediments, thereby improving the reliability and sustainable development of starch grain analysis results.

\section{Materials and Methods}

\subsection{Modern Deposits from Farmland and Nearby Secondary Vegetation}

The soil and temperature conditions of the North China Plain are ideal for dry farming systems compared to other areas in Northern China. At present, crops, such as millets, wheat (Triticum aestivum), and corn (Zea mays), are still abundantly planted in the North China Plain. We selected two sampling areas in the North China Plain for our study of modern surface soils. The first is a wheat field in Lijiaying Village in Shandong Province $\left(36^{\circ} 27^{\prime} 13^{\prime \prime} \mathrm{N}, 118^{\circ} 29^{\prime} 40^{\prime \prime} \mathrm{E}\right)$ (Figure 1a,b). Soils from the surrounding natural secondary vegetation within $2 \mathrm{~m}$ (horizontal distance) of the field (Figure 1c) were included in the sampling. The second area is a maize field in Tanghekou Village in Northern Beijing $\left(40^{\circ} 25^{\prime} 12^{\prime \prime} \mathrm{N}, 116^{\circ} 23^{\prime} 24^{\prime \prime} \mathrm{E}\right.$ ) (Figure 1a,d). Soil from the surrounding vegetation within $3 \mathrm{~m}$ (horizontal distance) of the cultivated area (Figure 1e) was also included.

The wheat field was located on a flatland in the eastern edge of the North China Plain, where the temperature, moisture, and irrigation are suitable for the growth of dry-farmed crops [23]. The variety of wheat (Triticum aestivum) being grown in Shandong Province was Yandan-13. This variety is typically sown in October, joints and heads in April, fills in May, and matures during or after June [23]. We confirmed this growing period with local farmers. Surface soil samples were collected in four sessions from the wheat field and surrounding areas: on 30 March 2011, when the wheat had begun to head and fill; on 15 June 2011, when the wheat had begun to mature; on 5 September 2011, after harvest; and on 20 January 2012, when the wheat was at the vernalization stage. 


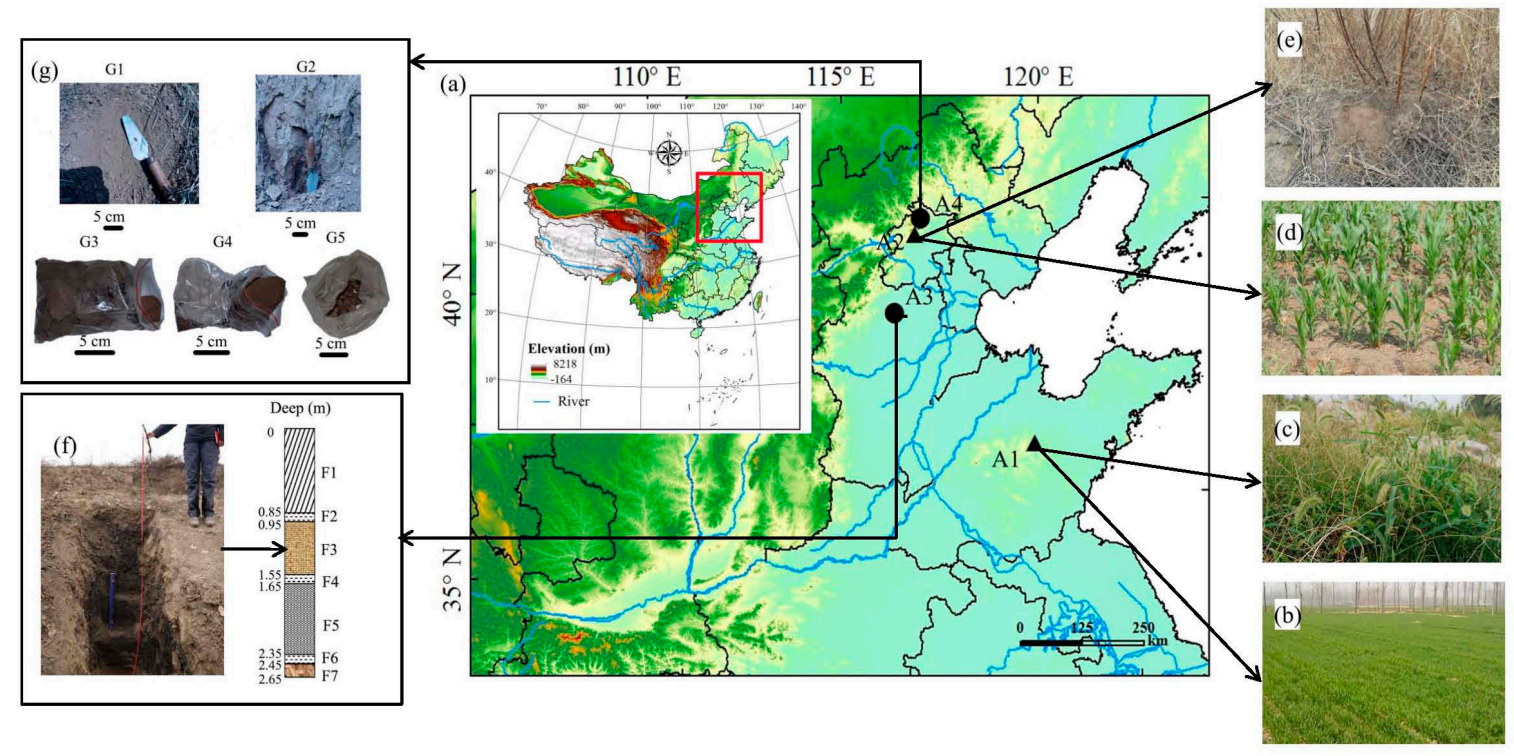

Figure 1. Location of the samples in this study. (a) Collection location of the surface soil and sedimentary samples. A1: the wheat field in Shandong Province; A2: the maize field in Beijing; A3: the Nanzhuangtou site; A4: the Zhuannian site; (b) the wheat field in Shandong Province; (c) the natural secondary vegetation near the wheat field in Shandong Province; (d) the maize field in Beijing; (e) the natural secondary vegetation near the maize field in Beijing; (f) the profile for samples in the Nanzhuangtou site. F1: surface soil; F2, F4, F6: transition layer; F3: overlying layer, F5: cultural sediments; F7: underlayer; and (g) soil samples from the Zhuannian site. G1: overlying layer; G2: underlayer; G3: cultural sediments from pit fillings; G4, G5: cultural sediments.

Surface soil samples were collected as follows. First, the operator randomly selected a $0.5 \times 0.5 \mathrm{~m}$ quadrat and removed foreign objects, such as rotten leaves and weeds. Next, while wearing powder-free nitrile gloves, the operator inserted a clean shovel from the surface to a depth of $2 \mathrm{~cm}$ and scooped $\sim 500 \mathrm{~g}$ soil samples into numbered sample bags. For each collection cycle, four samples were taken from the wheat field in four sampling sessions, and the other four samples were collected from the surrounding areas (Table 1).

During the third session (on 5 September 2011), in addition to the soil collection, plants, and seeds of mature wheat and secondary vegetation, mainly purslane (Portulaca oleracea), plantain (Plantago depressa), dandelion (Taraxacum mongolicum), grey amaranth (Chenopodium serotinum), goosegrass (Eleusine indica), and green bristlegrass (Setaria viridis), were gathered in numbered sample bags.

The maize field, which is near the archaeological site of Zhuannian, was located in a valley in the northern areas of the North China Plain. One variety of spring maize (Zea mays), MC-4592, is planted in mountainous areas in Northern Beijing. The maize is typically sown from late April to early May, joints and heads in June, pollinates and fills in July, and matures during or after August [24]. Local farmers and workers from the Seed Station of Beijing confirmed this growing period. Surface soil samples from a maize field and the surrounding vegetation were collected on the following days: 3 May 2012, when the maize germinated; 28 August 2012, when the maize matured; 2 December 2012, post-harvest; and 10 February 2013, before the following quarter sowing.

Sample collection methods for the maize field and surrounding areas were identical to the wheat field samples (Table 1). Plants and seeds of mature maize and secondary vegetation, mainly wormwood (Artemisia annua) and green bristlegrass, were gathered in numbered sample bags during the second sampling session on 28 August 2012. 
Table 1. Samples from farmland and nearby area.

\begin{tabular}{|c|c|c|c|c|c|}
\hline Horizons & Lab. No. & Depth $^{\text {a }}(\mathrm{m})$ & $\begin{array}{l}\text { Geographical } \\
\text { Coordinates }\end{array}$ & Weight (kg) & Soil Characteristic \\
\hline \multicolumn{6}{|c|}{ Samples from wheat field and surrounding area } \\
\hline \multirow{4}{*}{$\begin{array}{l}\text { Surface soils from } \\
\text { the wheat field }\end{array}$} & SX1 & \multirow{4}{*}{$0-0.02$} & $\begin{array}{l}36^{\circ} 27^{\prime} 13.58^{\prime \prime} \mathrm{N}, \\
118^{\circ} 29^{\prime} 41.22^{\prime \prime} \mathrm{E}\end{array}$ & 1.75 & \multirow{4}{*}{$\begin{array}{l}\text { Cinnamon colored, } \\
\text { fertile soils }\end{array}$} \\
\hline & $\mathrm{SX} 2$ & & $\begin{array}{l}36^{\circ} 27^{\prime} 13.23^{\prime \prime} \mathrm{N}, \\
118^{\circ} 29^{\prime} 40.55^{\prime \prime} \mathrm{E}\end{array}$ & 2.03 & \\
\hline & SX3 & & $\begin{array}{l}36^{\circ} 27^{\prime} 12.47^{\prime \prime} \mathrm{N} \\
118^{\circ} 29^{\prime} 40.22^{\prime \prime} \mathrm{E}\end{array}$ & 2.33 & \\
\hline & SX4 & & $\begin{array}{l}36^{\circ} 27^{\prime} 12.33^{\prime \prime} \mathrm{N}, \\
118^{\circ} 29^{\prime} 39.49^{\prime \prime} \mathrm{E}\end{array}$ & 2.08 & \\
\hline \multirow{4}{*}{$\begin{array}{l}\text { Surface soils from } \\
\text { surrounding area }\end{array}$} & SZ1 & \multirow{4}{*}{$0-0.02$} & $\begin{array}{l}36^{\circ} 26^{\prime} 15.58^{\prime \prime} \mathrm{N}, \\
118^{\circ} 30^{\prime} 41.48^{\prime \prime} \mathrm{E}\end{array}$ & 1.66 & \multirow{4}{*}{$\begin{array}{c}\text { Cinnamon colored, } \\
\text { fertile soils }\end{array}$} \\
\hline & SZ2 & & $\begin{array}{l}36^{\circ} 26^{\prime} 15.08^{\prime \prime} \mathrm{N}, \\
118^{\circ} 30^{\prime} 41.05^{\prime \prime} \mathrm{E}\end{array}$ & 1.78 & \\
\hline & SZ3 & & $\begin{array}{l}36^{\circ} 26^{\prime} 14.38^{\prime \prime} \mathrm{N}, \\
118^{\circ} 30^{\prime} 40.39^{\prime \prime} \mathrm{E}\end{array}$ & 1.80 & \\
\hline & $\mathrm{SZ} 4$ & & $\begin{array}{l}36^{\circ} 26^{\prime} 14.11^{\prime \prime} \mathrm{N}, \\
118^{\circ} 30^{\prime} 40.08^{\prime \prime} \mathrm{E}\end{array}$ & 1.93 & \\
\hline \multicolumn{6}{|c|}{ Samples from maize field and surrounding area } \\
\hline \multirow{4}{*}{$\begin{array}{l}\text { Surface soils from } \\
\text { maize field }\end{array}$} & BY1 & \multirow{4}{*}{$0-0.02$} & $\begin{array}{l}40^{\circ} 25^{\prime} 12.46^{\prime \prime} \mathrm{N}, \\
116^{\circ} 23^{\prime} 24.55^{\prime \prime} \mathrm{E}\end{array}$ & 2.46 & \multirow{4}{*}{ Sandy, barren soils } \\
\hline & BY2 & & $\begin{array}{l}40^{\circ} 25^{\prime} 12.06^{\prime \prime} \mathrm{N}, \\
116^{\circ} 23^{\prime} 24.03^{\prime \prime} \mathrm{E}\end{array}$ & 2.72 & \\
\hline & BY3 & & $\begin{array}{l}40^{\circ} 25^{\prime} 11.33^{\prime \prime} \mathrm{N}, \\
116^{\circ} 23^{\prime} 23.44^{\prime \prime} \mathrm{E}\end{array}$ & 2.83 & \\
\hline & BY4 & & $\begin{array}{l}40^{\circ} 25^{\prime} 11.01^{\prime \prime} \mathrm{N} \\
116^{\circ} 23^{\prime} 23.07^{\prime \prime} \mathrm{E}\end{array}$ & 2.32 & \\
\hline \multirow{4}{*}{$\begin{array}{l}\text { Surface soils from } \\
\text { surrounding area }\end{array}$} & BZ1 & \multirow{4}{*}{$0-0.02$} & $\begin{array}{l}40^{\circ} 26^{\prime} 15.11^{\prime \prime} \mathrm{N}, \\
116^{\circ} 24^{\prime} 25.26^{\prime \prime} \mathrm{E}\end{array}$ & 2.03 & \multirow{4}{*}{ Sandy, barren soils } \\
\hline & BZ2 & & $\begin{array}{l}40^{\circ} 26^{\prime} 14.43^{\prime \prime} \mathrm{N} \\
116^{\circ} 24^{\prime} 24.43^{\prime \prime} \mathrm{E}\end{array}$ & 2.16 & \\
\hline & BZ3 & & $\begin{array}{l}40^{\circ} 26^{\prime} 14.03^{\prime \prime} \mathrm{N} \\
116^{\circ} 24^{\prime} 24.03^{\prime \prime} \mathrm{E}\end{array}$ & 2.34 & \\
\hline & BZ4 & & $\begin{array}{l}40^{\circ} 26^{\prime} 13.23^{\prime \prime} \mathrm{N}, \\
116^{\circ} 24^{\prime} 23.88^{\prime \prime} \mathrm{E}\end{array}$ & 2.54 & \\
\hline
\end{tabular}

${ }^{a}$ Indicates the height of the distance from the ground.

\subsection{Sediments from the Archaeological Sites of Nanzhuangtou and Zhuannian}

Northern China is the center of domestication for both foxtail millet (Setaria italica) and broomcorn millet (Panicum miliaceum). At this time, the earliest evidence from both plant macroremains and microremains of these crops are from the North China Plain $[3,10]$. Sediments from deposits with clear, well-defined layers were chosen from two archaeological sites in this region that exhibit evidence of ancient plant use, the Nanzhuangtou site in Hebei Province and the Zhuannian site in Beijing (Figure 1a).

The Nanzhuangtou site $\left(39^{\circ} 6^{\prime} 40^{\prime \prime} \mathrm{N}, 115^{\circ} 39^{\prime} 25^{\prime \prime} \mathrm{E}\right)$ covers an area of $20,000 \mathrm{~m}^{2}$, and is located $1.7 \mathrm{~km}$ northeast of Nanzhuangtou Village, Xushui County, Hebei Province. Charred residues from organic material have been recovered here dating back to more than $11,000 \mathrm{cal}$ BP $[12,25]$. Three excavation seasons in 1986, 1987, and 1997 revealed the presence of major artifacts and features such as mullers, slabs, pottery sherds, and ditches $[25,26]$. Plant macroremains mainly 
included unidentified wood and leaves, water caltrop (Trapa natans), wild grape (Vitis bryonifolia), and pondweeds (Potamogeton spp.) [12], whereas microremains were primarily grasses, including millets (the tribe Paniceae), members of the tribe Triticeae, as well as unidentified roots and tubers [10]. Faunal remains included 1068 fragments of bones from sika deer (Cervus nippon), boar (Sus scrofa), and the domesticated dog (Canis familiaris) [26]. Twetny-four samples from the cultural sediment, its overlying layer, and its underlayer from the north wall of an excavation trench dug in 1997, as well as four samples from the surface soil of active farmland near the site (Figure 1f, Table 2) were analyzed via starch grain analysis.

Table 2. Sedimentary samples from the Nanzhuangtou and Zhuannian sites.

\begin{tabular}{|c|c|c|c|c|c|}
\hline Horizons & Lab. No. & Depth $^{a}(\mathrm{~m})$ & $\begin{array}{l}\text { Geographical } \\
\text { Coordinates }\end{array}$ & $\begin{array}{c}\text { Average } \\
\text { Weight (kg) }\end{array}$ & Characteristic \\
\hline \multicolumn{6}{|l|}{ Nanzhuangtou site } \\
\hline Underlayer & NZT1-NZT2 & $2.45-2.65$ & \multirow{7}{*}{$\begin{array}{r}39^{\circ} 6^{\prime} 40.33^{\prime \prime} \mathrm{N} \\
115^{\circ} 39^{\prime} 25.22^{\prime \prime} \mathrm{E}\end{array}$} & 0.66 & Yellow silt \\
\hline $\begin{array}{l}\text { Layer between } \\
\text { underlayer and } \\
\text { cultural sediment }\end{array}$ & NZT3 & $2.35-2.45$ & & 0.53 & Brown sandy silt \\
\hline Cultural sediments & NZT4-NZT16 & $1.65-2.35$ & & 0.48 & Brown silt clay \\
\hline $\begin{array}{c}\text { Layer between } \\
\text { cultural sediment } \\
\text { and overlying layer }\end{array}$ & NZT17 & $1.55-1.65$ & & 0.57 & $\begin{array}{l}\text { Shallow dark } \\
\text { brown silt clay }\end{array}$ \\
\hline Overlying layer & NZT18-NZT23 & $0.95-1.55$ & & 0.45 & Light brown silt \\
\hline $\begin{array}{c}\text { Layer between } \\
\text { overlying layer and } \\
\text { surface soil }\end{array}$ & NZT24 & $0.85-0.95$ & & 0.51 & Brown sandy silt \\
\hline Surface soil & NZT25-NZT28 & $0.00-0.85$ & & 0.33 & Yellow sandy silt \\
\hline \multicolumn{6}{|l|}{ Zhuannian site } \\
\hline Overlying layer & ZN1 & $0-0.05$ & \multirow{3}{*}{$\begin{array}{l}40^{\circ} 41^{\prime} 36.44^{\prime \prime} \mathrm{N} \\
116^{\circ} 36^{\prime} 18.25^{\prime \prime} \mathrm{E}\end{array}$} & 1.23 & Yellow silt \\
\hline Cultural sediments & ZN2-ZN4 & $0.50-0.90$ & & 1.45 & Light brown silt \\
\hline Underlayer & ZN5 & $1.20-1.35$ & & 1.28 & Brown silt \\
\hline
\end{tabular}

The Zhuannian site $\left(40^{\circ} 41^{\prime} 36^{\prime \prime} \mathrm{N}, 116^{\circ} 36^{\prime} 18^{\prime \prime} \mathrm{E}\right)$ covers an area of $5000 \mathrm{~m}^{2}$ and is located on the second terrace of the Baihe River, north of Beijing (Figure 1a). Radiocarbon dating of charcoal, nutshell, and organic sediment collected from the cultural deposits revealed that the site was occupied more than 10,000 cal BP [11]. Three excavations in 1992, 1995, and 1996 uncovered cultural deposits that measure between 0.8 and $1.0 \mathrm{~m}$ in thickness, and over 18,000 stone tools, including microblades, ground slabs, mullers, and stone containers were recovered [27]. Botanical macroremains included more than 50 fragments of Manchurian walnut (Juglans mandshurica) nutshells [12], while the microbotanical assemblage included starches from millets, members of the grass tribe Triticeae, and an unidentified type of geophyte [11]. Three samples of clearly-defined cultural sediments were collected including two samples from the cultural layer and a sample from pit fill. The other two samples were collected from both the underlayer and overlying layer of the cultural deposit (Figure 1f, Table 2).

\subsection{Starch Grain Analysis}

To recover starch grains from the soil and plant samples, we prepared slides for observation under a compound light microscope, following the methods of Piperno et al. [16], Perry [28], Li et al. [29], Yang et al. [30], and Yang and Perry [31]. Previous studies have demonstrated that starch grains with maximum length measurements of $<5 \mu \mathrm{m}$ are difficult to detect via compound light microscopy, 
are rarely diagnostic for taxa, and occur in many plant tissues [32-35]. Therefore, observations and statistical analyses were only performed on starch grains that measured $>5 \mu \mathrm{m}$.

Soil and sedimentary samples: (1) a $2 \mathrm{~mm}$ sieve was used to separate soil and sedimentary samples; (2) post-sieving, $5 \mathrm{~g}$ samples were weighed on an electronic scale; (3) samples were ground into a fine powder with a mortar; (4) a solution of $10 \% \mathrm{HCl}$ was used to remove calcium impurities; (5) samples were separated using a $250 \mu \mathrm{m}$ sieve, and grain size greater than $250 \mu \mathrm{m}$ were discarded; (6) larger particles were broken down with $6 \% \mathrm{H}_{2} \mathrm{O}_{2}$ to release starch grains potentially trapped within the sediment matrix; (7) a 5\% solution of sodium hexametaphosphate (Calgon) was added to deflocculate clay minerals and ease the dispersal of sediment samples; (8) starch grains were isolated via heavy liquid flotation using a solution of $\mathrm{CsCl}$ at adensity of $1.8 \mathrm{~g} / \mathrm{cm}^{3}$; and (9) the recovered residue was mounted on a slide in a solution of $10 \%$ glycerine and $90 \%$ ultrapure water. The slide was then sealed with nail polish.

Modern plant seeds: (1) ten seeds of each collected plant were placed in test tubes with $10 \mathrm{~mL}$ of ultrapure water for $12 \mathrm{~h}$, after which they were gently crushed with clean, glass stirring rods to release the starches; and (2) the solution of water and starch was then pipetted on to a clean glass slide, then mounted in 10\% glycerine and $90 \%$ ultrapure water. Again, the slide was sealed with nail polish and a cover glass.

\section{Results}

\subsection{Samples from Wheat Field Soil and Plant Seeds}

No starch grains were recovered from the eight soil samples from the field and the surrounding area covered by the natural secondary vegetation near the wheat field.

For the modern wheat seed samples, we recorded morphological data for 126 starch grains including 103 large Type A ( $>10 \mu \mathrm{m}$; mean, $20.5 \pm 4.3 \mu \mathrm{m}$; range, 11.0-34.4 $\mu \mathrm{m}$ ) and 23 small Type B (mean, $7.6 \pm 1.2 \mu \mathrm{m}$; range, 5.6-9.7 $\mu \mathrm{m}$ )within the bimodal distribution. The large, diagnostic Type A starch grains are characterized by a lenticular shape with a centric hilum. Some possessed lamellae and craters on the surface. The starch grains were olivary in shape and the equatorial groove appeared as a longitudinal dent when the grains were rotated (Figure $2 a-c)$. These observations are consistent with the large body of literature on wheat starch grains $[17,36]$.

All starch grains extracted from the seeds of the purslane, plantain, dandelion, grey amaranth, and goosegrass seed samples growing near the wheat field measured $<5 \mu \mathrm{m}$ in size. The morphological characteristics on the surfaces of starches $<5 \mu \mathrm{m}$ were unclear even at $400 \times$ magnification, and this size class of starch is always excluded from our archaeobotanical analyses. Starches from green bristlegrass have grains that measure $>5 \mu \mathrm{m}$, with a mean length of $6.8 \pm 1.4 \mu \mathrm{m}(n=143$; range, 5.1-9.2 $\mu \mathrm{m})$. Our observations demonstrate that green bristlegrass grains have a polyhedral or semi-round shape, centric hilum, and rough edges, with occasional transverse fissures (Figure 2d). The consistently small size, however, eliminates them from potential inclusion within a starch assemblage from any crop plants in the region.

\subsection{Samples from Maize Field Soil and Plant Seeds}

Like in the samples from the modern wheat fields, no starch grains were recovered from the four soil samples from the maize field and the surrounding area covered by natural secondary vegetation.

The starch grains of the modern maize seeds we studied possessed both irregular and spherical shapes (Figure 2e). The irregular grains were characterized by rough edges and wrinkled surfaces, while the spherical grains were smooth. The mean maximum length of the starch grains was $13.8 \pm 1.4 \mu \mathrm{m}$, ranging from 8.4 to $21.3 \mu \mathrm{m}(n=123)$. These observations are consistent with the large body of literature that addresses maize starch grain morphology [37]. 

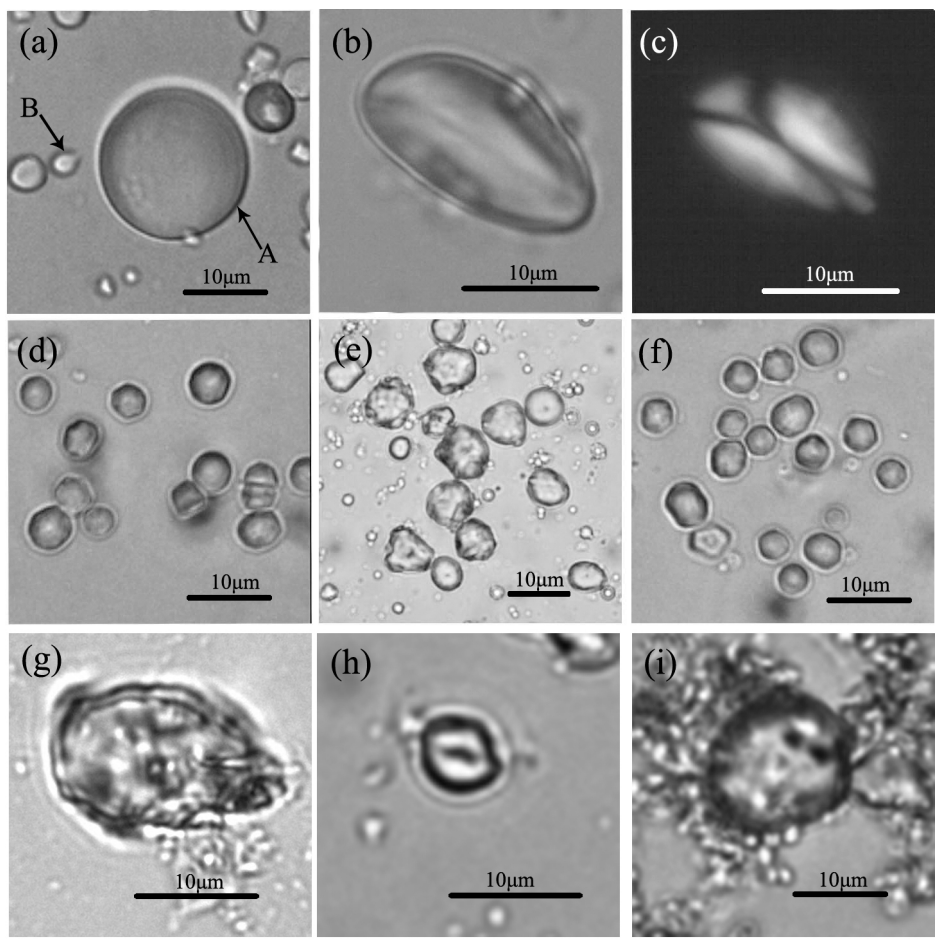

Figure 2. Starch grains from modern plant seeds, surface soils and sediments. (a-c) Starch grains from wheat seeds; (d) starch grains from green bristlegrass seeds from Shandong Province; (e) starch grains from maize seeds; (f) starch grains from green bristlegrass seeds from Beijing; (g) starch grain from the cultural layer of the Nanzhuangtou site; and (h,i) Starch grains from the cultural layer of the Zhuannian site.

Starch grains extracted from the wormwood seeds were all $<5 \mu \mathrm{m}$ and their surface morphological characteristics were unclear at $400 \times$ magnification. Green bristlegrass starch grains exhibited a mean maximum length of $6.4 \pm 1.3 \mu \mathrm{m}(n=132$; range, 5.3-9.1 $\mu \mathrm{m})$, and their morphological characteristics (Figure 2f) were like those noted in the green bristlegrass from Shandong Province.

\subsection{Samples from Sediments at the Nanzhuangtou Site}

Among the 28 sedimentary samples from the cultural layer, its overlying layer, and its underlayer, only one starch grain was recovered, and it was from the cultural sediment (No. NZT6, $n=1$; Table 2). The grain is $19.4 \mu \mathrm{m}$ in maximum length, exhibits a polygonal shape, a centric hilum, and rough edges (Figure 2g), but could not be identified because of surface damage on one side.

\subsection{Samples from Sediments at the Zhuannian Site}

No starch grains were recovered from the two sedimentary samples of the overlying layer and underlayer of cultural deposits, but three starch grains were recovered from two of the three cultural sediment samples (No. ZN3, $n=1$; No. ZN4, $n=2$; Table 2). Two grains are small (6.3 and $7.5 \mu \mathrm{m}$ in length) and possessed no identifiable features (Figure 2h), whereas the remaining grain is $16.9 \mu \mathrm{m}$ in length, polyhedral, and has a wrinkled surface (Figure 2i). This last grain exhibits similarities to the diagnostic morphological characteristics of millet starch grains, according to a dichotomous key derived from modern millet seed samples [30]. However, because only one grain was recovered, we could not make a positive identification. 


\section{Discussion}

\subsection{The Soil from the Farmland and Its Surrounding Area}

Despite the presence of multiple plant species that seasonally produce starch-rich seeds, no starch grains were recovered from the surface soils of the active wheat or maize fields and the surrounding areas. Our results support the results of previous studies that demonstrated that starch grains from modern plant seeds do not preserve in surface soils [10,11].

Starch grains from the seeds of the purslane, plantain, dandelion, grey amaranth, goosegrass, and wormwood seed samples growing near the wheat and maize field measured $<5 \mu \mathrm{m}$ in size. Previous studies have demonstrated that starch grains with maximum length measurements of $<5 \mu \mathrm{m}$ are difficult to detect via compound light microscopy [32,33]. Starch grains from the seeds of the wheat, maize and green bristlegrass seed samples measured $>5 \mu \mathrm{m}$ in size. Thus, a caveat of our results is that the starch grains of several weed species were of such small size that they are not subject to reliable detection under a microscope. However, this experimental artifact cannot fully explain why we did not observe larger starch grains in the study areas. The complex interactions of multiple cultural and natural activities in, and surrounding, any sediment make it impossible to be certain which ones may or may not be responsible for the absence of starches. Thus, we present the following factors as possibilities to be further studied and tested rather than certainties.

\subsubsection{Harvesting Methods}

In Shandong Province, the majority of farmers use mechanical combine harvesters for wheat harvesting, threshing, and winnowing. Subsequently, any straw and remaining surface vegetation are burned to prepare the fields for the next wave of sowing (personal communication, local farmers from Lijiaying Village). In contrast to the wheat operations, the maize fields of Beijing are quite small in size, so farmers typically harvest by hand and use the remaining maize stems for livestock feed or fuel (personal communication, local farmers and Yanpeng Zhao from the Seed Station of Beijing). Although harvesting methods differ overall, one notable similarity is that during both harvest and post-harvest clean-up, most of the crop seeds and stems are removed from the fields. Thus, the opportunity for starch grains to infiltrate surface soils is considerably minimized.

\subsubsection{The Presence of Wildlife and Microorganisms}

After harvesting, although most of the crop seeds and stems are removed from fields, some seeds may be left behind for several reasons, for example, early mature ears falling before harvest, or over ripe ears entering into soil during harvest. These seeds would be subject to predation by wildlife and soil microorganisms, thus eliminating their potential contribution to the starch grain population in the soils.

Research investigating the food reserves of ant colonies, for example, found that the insects primarily consume crop and weed seeds [37-40]. Brown rats, who ingest approximately $31.84 \mathrm{~g}$ of plant food per individual per day, are documented to consume nearly 40 species of crops and field weeds, spread across 16 families via studiesbased on artificial rearing, field investigation, and studies of the digestive system [41,42]. Next, sparrows are granivores that feed on a wide variety of plants, including crops, such as broomcorn millet, foxtail millet, wheat, maize, and sorghum (Sorghum bicolor), as well as weeds including those in the Poaceae (e.g., green bristlegrass) and Chenopodiaceae families [43]. Thus, some seeds that may have fallen to the ground during harvesting were probably consumed by the abundant seed predators in the area.

Seeds that are not consumed or digested by granivores are likely to be decomposed by soil bacteria and fungi, which are known to break down most organic matter[19,44,45] with decomposition rates as high as $95-99 \%$ [46,47]. Seeds that have been partially digested or broken by other seed predators would be particularly vulnerable to these decomposers. 
Thus, in combination, seed predators and the activities of microorganisms are likely to minimize the presence of starch grains in surface soils.

\subsubsection{Seed Biology}

Some seeds that are not destroyed by granivoresand soil microorganisms may survive. Seeds, generally speaking, are covered with a seed coat that both protects the embryo and absorbs moisture for germination [48]. As a self-protection mechanism, the seed coat is extremely durable and difficult to damage. Weed seeds, in particular, have been documented to have durable seed coats that are designed to conserve the embryo's food resources, starch, until germination [49]. Thus, the very nature of seed biology protects the embryonic plant and prevents starch grains from being released into the soil by keeping seeds intact until germination.

When the temperature, light conditions, water regimes, or other factors are favorable to germination, the starches in seeds, are converted to sugars and are consumed by the growing embryo. Crop seeds in particular may be more prone to germination and, therefore, the consumption of any starch grains due to characteristics that developed with domestication including, but not limited to, the loss of natural inhibitory mechanisms that prevent germination in wild plant seeds [50]. If they escaped human collection and seed predation, wheat and maize seeds would consume their own starch reserves during this process, thus preventing the starch grains from entering the soil.

\subsection{Sediments at the Archaeological Sites}

We did not recover any starch grains from the sediments of either the overlying layer or the underlayer of the cultural deposits at either the Nanzhuangtou or Zhuannian sites. As in the farmland and surrounding soils, we do not have a clear understanding of why there are no starch grains in these sediments. It may be that the same processes mentioned above were at work when these same soils lay on the surface. These factors are also combined, however, with long-term taphonomic processes that can destroy starch grains.

In contrast, samples from the cultural layers contained low concentrations of starch grains (approximately $0.2 \mathrm{n} / \mathrm{g}$ in Nanzhuangtou stie, $0.2 \mathrm{n} /$ gand $0.4 \mathrm{n} / \mathrm{g}$ in Zhuannian site). Our results, thus, corroborate previous research that recovered starch grains from cultural sediment samples at both the Nanzhuangtou and Zhuannian sites $[10,11]$. The starch grain types and concentrations reported in this study are far lower than those reported for the surface residues of artifacts from the same cultural layers. More than 20 starch grains of cereals, particularly millets, and acorns were recovered from three pottery sherds [10], and 408 starch grains of millets, the tribe Triticeae, tubers, and roots were recovered from one slab and one muller from the Nanzhuangtou site [10]. Despite these large differences in concentrations, the presence of starch grains in the samples from the cultural layers is enough to cause some concern.

The presence of starch grains in sediments from cultural layers is likely due to the hulling, grinding, and other food preparation processes of ancient humans while they prepared starchy foods for consumption. In contrast to the intact or damaged seeds left in the fields, these activities may have scattered a larger number of starch grains into the sediments than would field activities, and some of them, for reasons that are not clearly understood (e.g., the scattered starches result in the proliferation of microorganisms that begin to decompose the starches, then secretions from dead microorganisms adhere to the remaining starches and prevent their further decomposition, eventually allowing them to be preserved [51]), survived the predators and microorganisms.

To summarize, we did not recover starch grains from farmlands, their surrounding areas, or the overlying layers and underlayers of cultural deposits at archaeological sites. Thus, these sediments did not contaminate the archaeological tools in our studies, and similar sediments would not pose a threat to adjacent archaeobotanical analyses. We should note, however, that the current experiment examined only cereals. Future studies should examine the soil from field for cultivation of roots and tubers (e.g., yam (Dioscorea opposita), potato (Solanum tuberosum)). More experiments should 
also be undertaken that investigate the soil starch grain content under different cultivation and harvesting methods.

Starch grains were recovered from sediments collected from cultural layers at the sites. Our findings from the other layers indicate that these starch deposits are likely the result of cultural activities at the sites. Thus, when using starch grain analysis to interpret artifact function, it is important to collect and analyze sediments that are adjacent to artifacts so that comparisons can be made between any "background" levels of starch grains and the numbers and types of starches that occur on the tools themselves.

\section{Conclusions}

This study examined soil samples from wheat and maize fields, as well as sediment samples from two archaeological sites. Our results demonstrate that starch grains occurred only in the cultural deposits at Nanzhuangtou and Zhuannian in Northern China, suggesting that archaeological artifacts were unlikely to be contaminated by successive deposits after they areabandoned and buried. Simple methods that include the analysis of adjacent sediments in addition to the artifacts under study will allow for the clear understanding of the types of starch residues that are directly related to tool use.

Acknowledgments: This work was supported by the National Natural Science Foundation of China (41371217 and 41072140), the China Postdoctoral Science Foundation (2015M570006), and the National Science and Technology Major Project of China (2015CB953801). The authors thank Professor Jun Li from Shanxi University and Professor Jincheng Yu from the Beijing Institute of Cultural Relics for their help in sample collection from the archaeological sites of Nanzhuangtou and Zhuannian. We thank Yanpeng Zhao of the Seed Station of Beijing for providing information on maize growth and the maize field used for collecting surface soils in Beijing.

Author Contributions: X.Y. conceived and designed the study, and also performed the analytical model. Z.M. was responsible for the paper writing process, wrote large parts of the paper, and led the development of the framework as well as the data analysis. C.Z., Q.L. and L.P. contributed to the development of the framework, the ata analysis and drafted the article. All authors discussed the results and implications and commented on the paper at all stages.

Conflicts of Interest: The authors declare no conflict of interest.

\section{References}

1. Fuller, D.Q.; Qin, L.; Zheng, Y.F.; Zhao, Z.J.; Chen, X.G.; Hosoya, L.A.; Sun, G.P. The domestication process and domestication rate in rice: Spikelet bases from the Lower Yangtze. Science 2009, 323, 1607-1610. [CrossRef] [PubMed]

2. Hjelle, K.L.; Solem, T.; Halvorsen, L.S.; Astveit, L.I. Human impact and landscape utilization from the Mesolithic to medieval time traced by high spatial resolution pollen analysis and numerical methods. J. Archaeol. Sci. 2012, 39, 1368-1379. [CrossRef]

3. Lu, H.Y.; Zhang, J.P.; Liu, K.; Wu, N.Q.; Li, Y.M.; Zhou, K.S.; Ye, M.L.; Zhang, T.Y.; Zhang, H.J.; Yang, X.; et al. Earliest domestication of common millet (Panicum miliaceum) in East Asia extended to 10,000 years ago. Proc. Natl. Acad. Sci. USA 2009, 106, 7367-7372. [CrossRef] [PubMed]

4. Piperno, D.R.; Dillehay, T.D. Starch grains on human teeth reveal early broad crop diet in northern Peru. Proc. Natl. Acad. Sci. USA 2008, 105, 19622-19627. [CrossRef] [PubMed]

5. Piperno, D.R.; Holst, I. The presence of starch grains on prehistoric stone tools from the humid Neotropic: Indications of early tuber use and agriculture in Panama. J. Archaeol. Sci. 1998, 25, 765-776. [CrossRef]

6. Perry, L.; Dickau, R.; Zarrillo, S.; Holst, I.; Pearsall, D.M.; Piperno, D.R.; Berman, M.J.; Cooke, R.G.; Rademaker, K.; Ranere, A.J.; et al. Starch fossils and the domestication and dispersal of chili peppers (Capsicum spp. L.) in the Americas. Science 2007, 315, 986-988. [CrossRef] [PubMed]

7. Mercader, J. Mozambican grass seed consumption during the Middle Stone Age. Science 2009, 326, 1680-1683. [CrossRef] [PubMed]

8. Mark, H.; Ian, B. Microfossils of introduced starch cultigens from an early wetland ditch in New Zealand. Archaeol. Ocean. 2005, 40, 106-114.

9. Yang, X.Y.; Yu, J.C.; Lu, H.Y.; Cui, T.X.; Guo, J.N.; Ge, Q.S. Starch grains analysis reveals function of grinding stone tools at Shangzhai site, Beijing. Sci. China Ser. D 2009, 52, 1164-1171. [CrossRef] 
10. Yang, X.Y.; Wan, Z.W.; Perry, L.; Lu, H.Y.; Wang, Q.; Zhao, C.H.; Li, J.; Xie, F.; Yu, J.C.; Cui, T.X.; et al. Early millet use in northern China. Proc. Natl. Acad. Sci. USA 2012, 109, 3726-3730. [CrossRef] [PubMed]

11. Yang, X.Y.; Ma, Z.K.; Wang, T.; Perry, L.; Li, Q.; Huan, X.J.; Yu, J.C. Starch grain evidence reveals early pottery function cooking plant foods in North China. Chin. Sci. Bull. 2014, 59, 4352-4358. [CrossRef]

12. Yang, X.Y.; Ma, Z.K.; Li, J.; Yu, J.C.; Stevens, C.; Zhuang, Y.J. Comparing subsistence strategies in different landscapes of North China 10000 years ago. Holocene 2015, 25, 1957-1964. [CrossRef]

13. Yang, X.Y.; Fuller, D.Q.; Huan, X.J.; Perry, L.; Li, Q.; Li, Z.; Zhang, J.P.; Ma, Z.K.; Zhuang, Y.J.; Jiang, L.P.; et al. Barnyard grasses were processed with rice around 10,000 years ago. Sci. Rep. 2015, 5, 16251. [CrossRef] [PubMed]

14. Liu, L.; Bestel, S.; Shi, J.M.; Song, Y.H.; Chen, X.C. Paleolithic human exploitation of plant foods during the last glacial maximum in North China. Proc. Natl. Acad. Sci. USA 2013, 110, 5380-5385. [CrossRef] [PubMed]

15. Ugent, D.; Pozorski, S.; Pozorski, T. Prehistoric remains of the sweet potato from the Casma valley of Peru. Phytologia 1981, 49, 401-415.

16. Piperno, D.R.; Ranere, A.J.; Holst, I.; Hansell, P. Starch grains reveal early root crop horticulture in the Panamanian tropical forest. Nature 2000, 407, 894-897. [CrossRef] [PubMed]

17. Piperno, D.R.; Weiss, E.; Holst, I.; Nadel, D. Processing of wild cereal grains in the Upper Paleolithic revealed by starch grain analysis. Nature 2004, 430, 670-673. [CrossRef] [PubMed]

18. Grace, R. Use-wear analysis. The state of the art. Archaeometry 1996, 38, 209-229. [CrossRef]

19. Haslam, M. The decomposition of starch grains in soils: Implications for archaeological residue analyses. J. Archaeol. Sci. 2004, 31, 1715-1734. [CrossRef]

20. Haslam, M. Initial Tests on the Three-Dimensional Movement of Starch in Sediments. Available online: http:/ / press-files.anu.edu.au/downloads/press/p55631/pdf/ch0711.pdf (accessed on 25 April 2017).

21. Therin, M. Therin, M. The movement of starch grains in sediments. In Frontiers of Landscape Archaeology; Layton, R., Ucko, P., Austin, D., Eds.; Routledge: London, UK, 1998; pp. 61-72.

22. Williamson, B.S. Investigation of potential contamination on stone tools. In Ancient Starch Research; Torrence, R., Barton, H., Eds.; Left Coast Press: Walnut Creek, CA, USA, 2006; pp. 89-90.

23. Zhao, J.S.; Jing, S.M.; Wang, F.H. The study of wheat's ecological region in Shandong Province. Shandong Agric. Sci. 1992, 6, 3-8. (In Chinese)

24. Zhao, H.F.; Zhang, F.R.; Li, J.; Tang, H. Direction of agricultural development of urban Beijing-Single-harvest spring-maize farming method. Chin. J. Eco-Agric. 2008, 16, 469-474. [CrossRef]

25. Baoding Municipal Administration of Cultural Relics; Xushui County Office for Preservation of Ancient Monuments; Peking University; Hebei University. Test excavation to Nanzhuangtou site in Xushui County, Hebei Province. Archaeology 1992, 11, 961-971. (In Chinese)

26. Hebei Provincial Institute of Cultural Relics; Baoding Municipal Administration of Cultural Relics; Xushui County Office for Preservation of Ancient Monuments; Shanxi University. Excavation to Nanzhuangtou site in Xushui County, Hebei in 1997. Acta Archaeol. Sin. 2010, 3, 361-384. (In Chinese)

27. Yu, J.C. Features of early Neolithic culture in North China Plain as seen at the Zhuannian site. Beijing Cult. Relic. Archaeol. 2002, 5, 37-43. (In Chinese)

28. Perry, L. Starch analyses reveal the relationship between tool type and function: An example from the Orinoco valley of Venezuela. J. Archaeol. Sci. 2004, 31, 1069-1081. [CrossRef]

29. Li, M.Q.; Ge, Q.S.; Wang, Q.; Cai, L.H.; Ren, X.Y. Ancient starch grains from ash pits of Fengtai site, Qinghai Province and their application in archaeology. Quat. Sci. 2010, 30, 372-376. (In Chinese)

30. Yang, X.Y.; Zhang, J.P.; Perry, L.; Ma, Z.K.; Wan, Z.W.; Li, M.Q.; Diao, X.M.; Lu, H.Y. From the modern to the archaeological: Starch grains from millets and their wild relatives in China. J. Archaeol. Sci. 2012, 39, 247-254. [CrossRef]

31. Yang, X.Y.; Perry, L. Identification of ancient starch grains from the tribe Triticeae in the North China Plain. J. Archaeol. Sci. 2013, 40, 3170-3177. [CrossRef]

32. Moss, G.E. The microscopy of starch. In Examination and Analysis of Starch and Starch Products; Radley, J.A., Ed.; Applied Science Publications: London, UK, 1976; pp. 1-33.

33. Czaja, A.T. Structure of starch grains and classification of vascular plant families. TAXON 1978, $27,463-470$. [CrossRef]

34. Loy, T.H.; Springs, M.; Wickler, S. Direct evidence for human use of plants 28000 years ago: Starch residues on stone artifacts from the northern Solomon Islands. Antiquity 1992, 66, 898-912. [CrossRef] 
35. Barton, H.; Torrence, R.; Fullagar, R. Clues to stone tool function re-examined: Comparing starch grain frequencies on used and unused obsidian artefacts. J. Archaeol. Sci. 1998, 25, 1231-1238. [CrossRef]

36. Reichert, E.T. The Differentiation and Specificity of Starches in Relation to Genera, Species, etc.: Stereochemistry Applied to Protoplasmic Processes and Products, and as a Strictly Scientific Basis for the Classification of Plants and Animals; BiblioLife Press, Carnegie Institution of Washington: Washington, DC, USA, 1913; pp. 1-596.

37. Piperno, D.R.; Ranere, A.J.; Holst, I.; Iriarte, I.; Dickau, R. Starch grain and phytolith evidence for early ninth millennium B.P. maize from the Central Balsas River Valley, Mexico. Proc. Natl. Acad. Sci. USA 2009, 106, 5019-5024. [CrossRef] [PubMed]

38. Li, Q.X.; He, D.H.; Chang, Y.D.; Li, L.D. Research progress on forage behavior of ants. J. Ningxia Agric. Coll. 2000, 21, 94-97. (In Chinese)

39. Lu, Q.P.; Zhang, J.H.; Zhao, X.K.; Long, X.F.; Li, Z.L. Research on the food and ecological habits of the Black Ant. J. Hunan Univ. Arts Sci. (Nat. Sci. Ed.) 2008, 20, 42-45. (In Chinese)

40. Wheat. The Ant Agronomist. Available online: http://mall.cnki.net/magazine/Article/ZXBK201203024. htm (accessed on 25 April 2017). (In Chinese)

41. Wang, D.H.; Wang, Z.W.; Sun, R.Y. Variations in digestive tract morphology in root vole (Microtus oeconomus) and tis adaptive significance. Acta Theriol. Sin. 1995, 15, 53-59. (In Chinese)

42. Chen, X.R.; Yan, S.S. Research and application progress on rodent of Microtus. Endemic Dis. Bull. 2004, 19, 85-87. (In Chinese)

43. Guo, L. Studies on trophic analysis and control of sparrow. J. Hebei Acad. Sci. 2003, 20, 255-262. (In Chinese)

44. Loy, T.H. Prehistoric organic residue analysis: The future meets the past. In A community of Culture: The People and Prehistory of the Pacific; Spriggs, M., Yen, D.E., Amrose, W., Jones, R., Thorne, A., Andrews, A., Eds.; Australia National University, Research School of Pacific and Asian Studies: Canberra, Australia, 1993; pp. 56-72.

45. Dou, S. Soil Organic Matter; Science Press: Beijing, China, 2010; pp. 1-398. (In Chinese)

46. Andrews, R.; Coleman, D.C.; Ellis, J.E.; Singh, J.S. Energy Flow Relationships in a Shortgrass Prairie Ecosystem. Available online: http:/ / edepot.wur.nl/320441\#page=27 (accessed on 25 April 2017).

47. Jorgensen, B.B. Processes at the sediment-water interface. In The Major Biogeochemical Cycles and Their Interactions; Bolin, B., Cook, R.B., Eds.; SCOPE: Stockholm, Sweden, 1983; pp. 477-509.

48. Johnson, C.S.; Kolevski, B.; Smyth, D.R. TRANSPARENT TESTA GLABRA2, a trichome and seed coat development gene of Arabidopsis, encodes a WRKY transcription factor. Plant Cell 2002, 14, 1359-1375. [CrossRef] [PubMed]

49. Baskin, C.C.; Baskin, J.M. Seeds: Ecology, Biogeography and Evolution of Dormancy, and Germination, 1st ed.; Academic Press: San Diego, CA, USA, 1998; pp. 1-334.

50. Fuller, D.Q. Review: Contrasting patterns in crop domestication and domestication rates: Recent archaeobotanical insights from the Old World. Ann. Bot. 2007, 100, 903-924. [CrossRef] [PubMed]

51. Guggenberger, G.; Elliott, E.T.; Frey, S.D.; Six, J.; Paustian, K. Microbial contributions to the aggregation of a cultivated grassland soil amended with starch. Soil. Biol. Biochem. 1999, 31, 407-419. [CrossRef]

(C) 2017 by the authors. Licensee MDPI, Basel, Switzerland. This article is an open access article distributed under the terms and conditions of the Creative Commons Attribution (CC BY) license (http:/ / creativecommons.org/licenses/by/4.0/). 